\title{
Clinical Aspect of Diseases of Cornea in Ayurveda
}

\author{
Review Article
}

\section{Agarwal Riju ${ }^{1}$, Bhardwaj Atul ${ }^{2}$, Dhiman Kartar $S^{3}, \operatorname{Rani}_{\text {Manju }}{ }^{4}$}

\author{
1. Associate Professor \& Head, 2. Assistant Professor, Department of Shalakya, \\ 4. Associate Professor \& Head, Department of Shalya \\ CBPCAS, Khera Dabar, Najafgarh. New Delhi. \\ 3. Director General, CCRAS, New Delhi (Former Prof \& Head-Shalakya, IPGT\&RA, GAU, Jamnagar)
}

\begin{abstract}
Introduction: There are total seventy six ocular diseases described in Sushruta Samhita and 94 diseases in Astanga Sangrah \& Astanga Hridya. This concept of classification of ocular disorders is well buttressed by classifying the disease as Sandhigata (Diseases affecting junctional areas of eye), Vartamagata (Diseases of eyelids), Shuklagata (Diseases of Sclera plus Conjunctiva), Krishnagata (Diseases of Cornea), Sarvagata (Diseases affecting all parts of Eye), Drishtigata (Diseases of Lens). Material and Methods: Extensive literary review of various text of Ayurveda in order to carve out a possible comparison of Ayurvedic Corneal Ophthalmological disorders with modern counterpart. Aims: To establish clinical correlation between diseases of Krishna mandala to disease of the cornea. Discussion: Classifications of corneal diseases in classical Ayurvedic texts are sequential and progressive in nature viz. one condition progress to the next corresponding stage. A charya Sushruta described 4 types of diseases of cornea while Vagbhatta has enumerated 5 types. A conscious endeavor is made to correlate the Ayurvedic and modern corneal disorders in a complimentary manner. Conclusion: The congruent behavior of corneal disorders of Ayurved and modern is justified by the clinical symptomology, progression of the disease, prognostic reasons and relevant intervention. The integrated disease approach, treatment application and predicting prognosis will suffice the resultant outcome of the disease in a more favorable perspective which will herald a better approach in managing preventable corneal blindness.
\end{abstract}

Keywords: Akshi Pakatyaya, Ajakajata, Avrana Shukra, Cornea, Savrana Shukra, Siraja Shukra, Shalakya Tantra.

\section{Introduction}

Eye is the most intricate structure in the body. Two eyes provides about half the total sensory inputs from the entire body into the brain (1). In the Ayurvedic system of Medicine there are eight branches or specialty among these Shalakya Tantra deals with diseases of Supraclavicular region (2) i.e. Eye (Ophthalmology), ENT (Otorhinolaryngology), OroDental diseases (Oro-Dentistry), etc. When we go through literature of Ayurveda Ophthalmology follows a sequential systematic and elaborative description of disease pertaining to various disorders of eye components (3). First nineteen chapters of Uttaratantra of Sushruta Samhita are exclusively dedicated to Ophthalmological disorders which conspicuously reflex that the classical ophthalmological literature

*Corresponding Author:

Riju Agarwal,

Associate Professor, Department of Shalakya,

CBPCAS, Khera Dabar,

Najafgarh. New Delhi.

Ph.no: 9650570095

E-mail id: rijuagarwal@gmail.com well versed with subtle details even at that time. This didactic segment of ophthalmology is contributed by Vidhadhipati (4) (King of Videha - Raj rishi Nimi) in classical texts. Another established ophthalmological section is compiled by Acharya Vagbhatta which has detailed 10 chapter viz. 11-20 chapters of Astanga Sangrah Uttara sthana. According to him eye has been privileged as the main sense organ because its loss of function leads to serious disability of a man by keeping him in the darkness. Life without eyesight is miserable and valueless. Hence it is very important to protect vision at any cost (5).

Sushruta precisely described about Anatomy of Eye in first chapter i.e. Aaupdravik Adhyaya. There are total seventy six (6) ocular diseases described in Sushruta Samhita and 94 diseases in Astanga Sangrah \&Astanga Hridya (7) as an essence of our current Ayurvedic ophthalmological concepts. Sharangadhara (8) followed the traces of Vagbhatta while Yogratnakar (9) followed Sushruta in classification of Netra roga and their numbers. Bhavprakasha (10) described 78 diseases of Netra. The classification given in the Ayurvedic text is sequential and systematic as it encompasses the modern system of disease classification with its relevance guided on various structure of the eyeball. 
This concept of classification of ocular disorders is well buttressed by classifying the disease as Sandhigata (11) (Diseases affecting junctional areas of eye), Vartamagata (12) (Diseases of eyelids), Shuklagata (13) (Diseases of Sclera plus Conjunctiva), Krishnagata (14) (Diseases of Cornea), Sarvagata (15) (Diseases affecting all parts of Eye), Drishtigata (16) (Diseases of Lens). Ocular traumatology chapter $19^{\text {th }}$ (17)( Nayanabhighata) and Ocular therapeutics - Kriya Kalpa Vigyan (18) are the high points of Ayurvedic ophthalmology.

Material and Methods: Extensive literary review of various text of Ayurveda e.g. Sushruta Samhita, Astanga Sangrah, Astanga Hridya, Sharangadhara Samhita and Yogratnakar was done in order to carve out a possible comparison of Ayurvedic Corneal Ophthalmological disorders with modern counterpart. This endeavor also elucidates a conscious approach to establish a finesse correlation to be explored in order to attain a compatible behavior of these comparisons.

Aims: To establish clinical correlation between diseases of Krishna mandala to disease of cornea.

\section{Discussion:}

\section{Krishna Mandala}

Next to Shukla mandala (19) (white circle of eye or Sclera) there is Krishna Mandala (Black circle of eye) known as Cornea. Size of cornea is one third of Netra Aayaam (20) (Diameter of eye). Size of Pupil is one seventh of Cornea. Size of pupil in respect of Taraka is 1/9 (21). When we establish the congruent features of Taraka with its possible modern structure the properties of contraction \& relaxation (21) described in context to Taraka makes this structure as a potent choice to be correlated as Iris. Circumference of Iris is $1.5 \mathrm{~mm}$ larger than the circumference of Cornea that's why dimension of Drishti Mandala (Pupil) in respect of Cornea and Iris is different i.e. 1/7 \& 1/9 respectively.

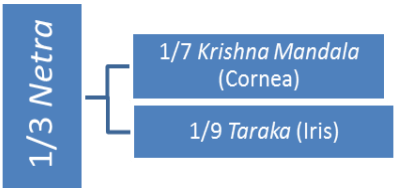

The anatomical proximity between cornea and iris, common nerve innervation, sharing nature of nutrients through aqueous also play an important role in simultaneous expression of pathology of these two structure. This concept is well appreciated in modern ophthalmology as pathology of one can affect other and also their treatment needs to be extrapolated to counter the disease of both cornea and iris.

\section{Diseases of Cornea in Ayurveda}

Classifications of corneal diseases in classical Ayurvedic texts are sequential and progressive in nature viz. one condition progress to the next corresponding stage. Acharya Sushruta described 4 types (22) of diseases of cornea while Vagbhatta has enumerated 5 types (23) which are tabulated below:
Table No.1 Enlisting of disease of Cornea

\begin{tabular}{|c|c|c|}
\hline $\begin{array}{l}\text { S } \\
\text { No. }\end{array}$ & Sushruta & Vagbhatta \\
\hline 1. & $\begin{array}{ll}\text { Savrana } & \text { Shukla } \\
\text { (Corneal } & \text { Ulcer) } \\
(24) & \\
\end{array}$ & $\begin{array}{llr}\text { Kshatta Shukla } & \text { (25) } \\
\text { (Corneal ulcer due } & \text { to } \\
\text { trauma) } & & \\
\end{array}$ \\
\hline 2. & $\begin{array}{l}\text { Avrana Shukla } \\
\text { (Corneal Opacity) } \\
(26)\end{array}$ & $\begin{array}{l}\text { Shudha Shukla } \\
\text { (Corneal Opacity) }\end{array}$ \\
\hline 3. & $\begin{array}{l}\text { Ajakajata (28) } \\
\text { (Prolapse of Iris) }\end{array}$ & Ajaka (29) (Prolapse of Iris) \\
\hline 4. & $\begin{array}{l}\text { Akshi Pakatyaya } \\
\text { (30) } \\
\text { (Panophthalmitis) }\end{array}$ & $\begin{array}{l}\text { Pakatyaya Shukra (31) \& } \\
\text { Akshipatayaya } \\
\text { (Described in Sarvakshiroga } \\
\text { roga (Panophthalmitis) }\end{array}$ \\
\hline 5. & ------ & $\begin{array}{lr}\text { Siraja Shukra } & \text { (33) } \\
\text { (Neovascularization } \\
\text { corneal ulcer) }\end{array}$ \\
\hline
\end{tabular}

Corneal diseases in modern literature are divided into four basic categories:

Ulcerative diseases (34)

Non - Ulcerative diseases (35)

Disorders of Corneal Degenerations (36)

Disorders of Corneal dystrophy (37)

The Ayurvedic corneal diseases which can be imbibed under the modern classification of corneal disorders is depicted as underneath

Savrana Shukra, Akshi Pakatyaya vis a vis Ulcerative Keratitis

Ajakajata and Siraja Shukra vis a vis complication of Ulcerative Keratitis (38) .

Avrana Shukra vis a vis Non-Ulcerative condition.

\section{Savrana Shukra (Ulcerative Keratitis) (24)}

If Krishna mandala (cornea) looks like that it is immersed in water (loses transparency or become edematous), pierced by needle (Corneal ulcer), copious warm discharge from the eye associated with severe pain then it is called Savrana Shukra. By this description it can be interpreted that basically there are four main symptoms described in Ayurveda for Savrana Shukra i. e.

There is corneal edema/ Loss of transparency which ultimately leads to decreased visual acquity.

Ulceration of the cornea

Copious discharge which is warm in nature indicating acute inflammation of cornea.

Severe pain/unbearable pain which are mostly found in deeper infection of eye mainly associated with ciliary congestion due to rich sensory supply of cornea.

According to A charya Videha (39).

In corneal ulcer there is neovascularization which is having appearance like coral and characteristics as described by Acharya Sushruta.

Acharya Vagbhatta has coined the Kshatta Shukra (25) (Ulcerative Keratitis caused by trauma), for this disease which itself indicate Traumatic origin. In addition to Sushruta few more symptoms were described by Acharya Vagbhatta in this disease, these are: 
Toda (Pricking sensation)

Raga (conjunctival congestion)

Pakwajambunibham (severely congested eye/ Ciliary congestion)

Prognosis of Savrana Shukra/Kshatta Shukra: in addition to the clinical features of the Savrana Shukra Aacharyas also described prognosis of Savrana Shukra on the basis of location, types, number, features etc.

Ulcers having following properties are considered as curable (40) :

- Ulceration away from central part of cornea viz. peripheral ulcer

- Superficial ulcer (involving only the epithelial layer of cornea)

- Non discharging ulcer (Absence of secondary infection)

- Painless Ulcer

- Solitary ulcer

Ulcers having following properties are incurable (41):

- Central corneal perforations

- Corneal ulceration which are covered with granulation tissue

- Concomitant existence of healed and newly formed ulcer which is frequent presentation of protozoal corneal ulcer.

- Neovascularization of central cornea. This condition is separately described by Acharya Vagbhatta as Siraja Shukra (33) .

- Involving two layer i.e. involvement of vascular coat along with fibrous coat result into complications and severe diminished visual acuity.

- Intraocular hemorrhage (Hyphaema) Neovascularization.

- Having copious warm discharge with corneal abscess

- Ulcer having grey white color like wing of quail indicative of severe necrosis of corneal layer/ necrotizing corneal ulcer.

- If ulcer lies in first layer i.e. Tejojalashrita Patala (42) of eyeball it is difficult to treat

- If it involve two layers i.e. Tejojalashrita and Mansashrita Patala (42) then it is Yapya (as long as medication and proper care is taken it do not complicate)

- If it affect three layers (42) i.e. first two coats followed by third tunic of eye which may be taken as Cortex of the lens.

Corneal ulcer having following properties is incurable in nature (47):

- Complete loss of vision (either there is corneal perforation or intraocular contents are not in condition to visualize anything).

- Ulcer which is grey from inside sometime having red color

- Hyper granulation tissue or very deep, with copious discharge,

- Presence of Sinus indicating there is continuous oozing of aqueous humour from this ulcerated site

- Chronic, when central portion get perforated are incurable conditions.

If there is chronic corneal ulceration or deep corneal ulcer then it will lead to Toxic Iridocyclitis (43) (which is involvement of second Patala according to Ayurveda) and chronic Uveitis would lead to Anterior Synechiae (44) and posterior synechiae (45) become Incurable. So in this case involvement of third Patala or after formation of Anterior and posterior synechiae ultimately leads to increased Intra ocular pressure (I.O.P.) of Eye and it will lead to further complication i.e. Secondary Glaucoma (46) which is still considered very difficult to treat. As a paradigm inference the cascade of complications of corneal ulcer has got close proximity with Ayurvedic opinion of disease progression in complicated corneal ulcers so much so that the incurable stages of corneal ulcer described in Ayurvedic literature can be systematically correlated with complicated corneal ulcer per se as outlined supra.

\section{Non-ulcerative condition of Cornea in Ayurveda 2- Avrana Shukra/Shudha Shukra (Corneal Opacity) $(26,27)$ :}

Avrana Shukla means opacity without ulcer which indicates healed corneal ulcer and the size of the opacity is directly proportional to size of the ulcer. According to Acharya Sushruta when a white spot appears in the cornea which is caused by Abhishyanda (Conjunctivitis) featuring relatively painless condition, devoid of lacrimation and looks like a white cloud in the sky. In context of prognosis he has demarcated his opinion by saying that dense, indurated and chronic in nature is said to be curable with difficulty.

The innocuous corneal ulceration looks like Shankha (Conch shell) which is white in color and featuring Kapha dosha having mild/no pain. Another prominent scholar Madhava in his epic Madhava Nidana has described features of innocuous corneal ulceration like shell/moon/white lotus or thin white clouds. This condition is considered curable both by Sushruta and Vagbhatta.

Complication of corneal ulcer in Ayurveda 3- Ajakajata (Perforated corneal ulcer) $(28,29)$

In this corneal disorder cornea gets perforated with prolapsed iris which has given classical resemblance with goat excreta. The clinical features of this disorder are severe pain and copious discharge. The prolapsed iris may be attributed classical black color because of reduced extirpated blood and its contact with external ambience. According to Ayurvedic texts the prolapsed iris having distinct red color, salty and thick blood mixed lacrimation with severe pain. It is Raktaja predominant incurable disease according to Sushruta while his treatise commentator Dalhana categorized it as Kaphaja predominant incurable disease (48).

Akshipatayaya/Pakatyaya Shukra
(Endophthalmitis/Panophthalmitis) $(30,31,32)$
The features of this disease include


comprehensively vitiated Tridosha which is manifested as white opacified cornea with excruciating pain. This stays well concurrent with complicated corneal ulcer in which eye become pus filled cavity emanating whitish hue from the cornea as in case of Hypopyon Corneal ulcer. So when corneal ulcer is secondarily infected, showing less propensity for healing, becomes excavated leading to severe inflammatory intraocular response. Hypopyon ulcer may complicates into the stage of Endophthalmitis or Panophthalmitis which after commencement becomes incurable. The reason which can be offered for this catastrophe is that the blood aqueous barrier which plays a major role in drug distribution is disrupted and hence no drug availability is possible in infected eye. Vagbhatta has suffixed the word Shukra along with Pakatyaya as it indicates that it is complication of Savrana Shukra.

Two additional features are described by Vagbhatta are:

- Complete corneal opacity

- Classical presentation of half cotyledon of Indian broad beans appearance which is highly suggestive of Hypopyon corneal ulcer (49).

Acharya Vagbhatta has also described another disease in Pan ocular disorder as Akshipatayaya. The characteristic features of this disease are ocular edema, congested eye ball, thick discharge, Leukomatous corneal opacity, burning sensation, diminution of vision and intermittent pain .

Some of the differentiating factors between Acharya Sushruta and Vagbhata regarding Akshipatayaya are tabulated as underneath:

Table No.2 Showing differentiating features of Akshipatayaya

\begin{tabular}{|l|l|l|}
\hline $\begin{array}{l}\text { S } \\
\text { No. }\end{array}$ & Sushruta & Vagbhatta \\
\hline 1. & Akshi Pakatyaya & Pakatyaya Shukla \\
\hline 2. & $\begin{array}{l}\text { Involvement of } \\
\text { Tridosha }\end{array}$ & $\begin{array}{l}\text { Involvement of Tridosha } \\
\text { with Rakta }\end{array}$ \\
\hline 3. & $\begin{array}{l}\text { Involvement of } \\
\text { cornea }\end{array}$ & $\begin{array}{l}\text { Involvement of cornea } \\
\text { and lens }\end{array}$ \\
\hline 4. & $\begin{array}{l}\text { Symptoms ar pain } \\
\text { described are pain, loss } \\
\text { and loss of vision }\end{array}$ & $\begin{array}{l}\text { Symptoms are paision, congestion, } \\
\text { of vensation, } \\
\text { burning } \\
\text { edema, inflammation }\end{array}$ \\
\hline
\end{tabular}

\section{5- Siraja Shukra (Neo vascularization of the Cornea)} (33)

This condition arises due to complication of corneal ulcer and described by Vagbhatta only. This is commonly found in chronic corneal ulcer as seen in some of the forms of keratoconjunctivitis. The disease is featured with corneal vascularization, pricking pain, burning sensation and copper colored cornea attributed to vitiated Rakta dosha. There is serosanguinous discharge of varied temperature of thick consistence without any cause. The disease at this particular stage shows little signs of recovery. The disease symptoms at this particular stage stays compatible with certain features of classical disorder termed as Savrana Shukra
4) Dr Riju Agarwal, Krishanagata Roga (Corneal disorders) - A comprehensive Analysis, Chapter 1, Delhi, published by author, 2015, P-1-2.

5) Vaidya Yadavji Trikamji and Narayan Ram Acharya, Sushruta Samhita Uttartantra 1/4, By Sushruta with Nibandhasngraha Commentry of Shri Dalhanacharya, Varanasi, Choukhamba Surbharti Prakashan, 2012, P-595.

of Sushruta. The précised compatible features are vascularization of cornea, pricking pain, burning sensation, ciliary congestion and varied temperature of lacrimation without non identifiable cause.

\section{Conclusion}

Classifications of corneal diseases in classical viz. one condition progress to the next corresponding stage. A charya Sushruta described 4 types of diseases of cornea while Vagbhatta has enumerated 5 types. This congruent behavior of corneal disorders of Ayurved and modern is justified by the clinical symptomology, progression of the disease, prognostic reasons and relevant intervention. In modern system diseases of cornea are classified into four types: Ulcerative Keratitis, Non Ulcerative Keratitis, Corneal Dystrophies and Corneal degeneration. The last two condition albeit have lacking significant congruent pathology in Ayurvedic literature but there are plethora of references which caters the first two identity viz. Ulcerative Keratitis, Non Ulcerative Keratitis. The integrated disease approach, treatment application and predicting prognosis will suffice the resultant outcome of the disease in a more favorable perspective which will corneal blindness.

\section{References}

1) Dereje Negussie, Yared Assefa, Atotibebu Kassa, Azanaw Melese, Ethiopia Public Health Training Initiative, Uninversity of Gondor, 2004, P-1.

2) Vaidya YadavjiTrikamji and Narayan Ram Acharya, Sushruta Samhita Uttartantra 6/6, By Sushruta with Nibandhasngraha Commentry of Shri Dalhanacharya, Varanasi, Choukhamba Sanskrita Sansthan, Edition reprint 2010, P-603. Acharya, Sushruta Samhita Sutrasthana 1/2, By Sushruta with Nibandhasngraha Commentry of Shri Dalhanacharya, Varanasi, Choukhamba Surbharti Prakashan, 2012, P-3.

6) Kaviraj Atridev Gupta, Ashtang Sangraha, Uttartantra $16 / 72$ by Vagbhata, Varanasi, Choukhamba Krishandas Academy, 2005, P-247.

7) Yadavji Trikamji and Narayan Ram Acharya, Sushruta Samhita Uttartantra 1/28, By Sushruta with Nibandhasngraha Commentry of Shri Dalhanacharya, Varanasi, Choukhamba Surbharti Prakashan, 2012, P-597.

8) Kaviraj Atridev Gupta, Ashtang Hridya, Uttartantra 16/60 By Vagbhata, Varanasi, Choukhamba Prakashan, 2012, P-690. Ayurvedic texts are sequential and progressive in nature 
9) Shailja Srivastava, Sharangdhara Samhita, Purvakhanda 7/153-170, By Sharangdhara, Varanasi, Chaukhamba Orientalia, 2009, P-114117.

10) Vaidya Lakshmipati Shastri, Yogratnakar, Netraroga adhikara/3-4, Varanasi, Chaukhamba Prakashan, 2012, P-341.

11) Brahma Sankara Mishra, Bhavprakash Part II 63/3-4, By Bhavamishra, Varanasi, Chaukhamba Sanskrit Bhawan, 2010, P--615.

12) Vaidya Yadavji Trikamji and Narayan Ram Acharya, Sushruta Samhita Uttartantra 2/3, By Sushruta with Nibandhasngraha Commentry of Shri Dalhanacharya, Varanasi, Choukhamba Surbharti Prakashan, 2012, P-598.

13) Vaidya Yadavji Trikamji and Narayan Ram Acharya, Sushruta Samhita Uttartantra 3/5-8, By Sushruta with Nibandhasngraha Commentry of Shri Dalhanacharya, Varanasi, Choukhamba Surbharti Prakashan, 2012, P-599.

14) Vaidya Yadavji Trikamji and Narayan Ram Acharya, Sushruta Samhita Uttartantra 4/3, By Sushruta with Nibandhasngraha Commentry of Shri Dalhanacharya, Varanasi, Choukhamba Surbharti Prakashan, 2012, P-601.

15) Vaidya Yadavji Trikamji and Narayan Ram Acharya, Sushruta Samhita Uttartantra 5/3, By Sushruta with Nibandhasngraha Commentry of Shri Dalhanacharya, Varanasi, Choukhamba Surbharti Prakashan, 2012, P-602.

16) Vaidya Yadavji Trikamji and Narayan Ram Acharya, Sushruta Samhita Uttartantra 6/4, By Sushruta with Nibandhasngraha Commentry of Shri Dalhanacharya, Varanasi, Choukhamba Surbharti Prakashan, 2012, P-603.

17) Vaidya Yadavji Trikamji and Narayan Ram Acharya, Sushruta Samhita Uttartantra 7/5, By Sushruta with Nibandhasngraha Commentry of Shri Dalhanacharya, Varanasi, Choukhamba Surbharti Prakashan, 2012, P-606.

18) Vaidya Yadavji Trikamji and Narayan Ram Acharya, Sushruta Samhita Uttartantra 19/1-2, By Sushruta with Nibandhasngraha Commentry of Shri Dalhanacharya, Varanasi, Choukhamba Surbharti Prakashan, 2012, P-640.

19) Vaidya Yadavji Trikamji and Narayan Ram Acharya, Sushruta Samhita Uttartantra 18/1, By Sushruta with Nibandhasngraha Commentry of Shri Dalhanacharya, Varanasi, Choukhamba Surbharti Prakashan, 2012, P-633.

20) Vaidya Yadavji Trikamji and Narayan Ram Acharya, Sushruta Samhita Uttartantra 1/15, By Sushruta with Nibandhasngraha Commentry of Shri Dalhanacharya, Varanasi, Choukhamba Surbharti Prakashan, 2012, P-596.

21) Vaidya Yadavji Trikamji and Narayan Ram Acharya, Sushruta Samhita Uttartantra 1/12-13, By Sushruta with Nibandhasngraha Commentry of Shri Dalhanacharya, Varanasi, Choukhamba Surbharti Prakashan, 2012, P-596.

22) Ambika dutta shastri, Sushruta Samhita Sutrasthana35/14, Part I, By Sushrutha with
Ayurveda Tantvasandipika commentary, Varanasi, Choukhamba Sanskrit Sansthan, 1997, P-131.

23) Vaidya Yadavji Trikamji and Narayan Ram Acharya, Sushruta Samhita Uttartantra 5/3, By Sushruta with Nibandhasngraha Commentry of Shri Dalhanacharya, Varanasi, Choukhamba Surbharti Prakashan, 2012, P-602.

24) Kaviraj Atridev Gupta, Ashtang Sangraha, Uttartantra $13 / 26-30$ by Vagbhata, Varanasi, Choukhamba Krishandas Academy, 2005, P-234.

25) Ambika dutta shastri, Sushruta Samhita Uttartantra 5/4, Part I, By Sushrutha with Ayurveda Tantvasandipika commentary, Varanasi, Choukhamba Sanskrit Sansthan, 2012, P-29.

26) Kaviraj Atridev Gupta, Ashtang Sangraha, Uttartantra $13 / 26$ by Vagbhata, Varanasi, Choukhamba Krishandas Academy, 2005, P-234.

27) Vaidya Yadavji Trikamji and Narayan Ram Acharya, Sushruta Samhita Uttartantra 5/8, By Sushruta with Nibandhasngraha Commentry of Shri Dalhanacharya, Varanasi, Choukhamba Surbharti Prakashan, 2012, P-602.

28) Kaviraj Atridev Gupta, Ashtang Sangraha, Uttartantra $13 / 27$ by Vagbhata, Varanasi, Choukhamba Krishandas Academy, 2005, P-234.

29) Ambika dutta shastri, Sushruta Samhita Uttartantra 5/9, Part II, By Sushrutha with Ayurveda Tantvasandipika commentary, Varanasi, Choukhamba Sanskrit Sansthan, 2012, P-32.

30) Kaviraj Atridev Gupta, Ashtang Sangraha, Vol II, Uttartantra $13 / 28$ by Vagbhata, Varanasi, Choukhamba Krishandas Academy, 2005, P-234.

31) Vaidya Yadavji Trikamji and Narayan Ram Acharya, Sushruta Samhita Uttartantra 5/9, By Sushruta with Nibandhasngraha Commentry of Shri Dalhanacharya, Varanasi, Choukhamba Surbharti Prakashan, 2012, P-603.

32) Kaviraj Atridev Gupta, Ashtang Sangraha, Uttartantra $13 / 30$ by Vagbhata, Varanasi, Choukhamba Krishandas Academy, 2005, P-234.

33) Kaviraj Atridev Gupta, Ashtang Sangraha, Uttarsthana $18 / 17$ by Vagbhata, Varanasi, Choukhamba Krishandas Academy, 2005, P-252.

34) Kaviraj Atridev Gupta, Ashtang Sangraha, Uttarsthana $13 / 29$ by Vagbhata, Varanasi, Choukhamba Krishandas Academy, 2005, P-234.

35) Khurana AK, Comprehensive Ophthamology, Diseases of Cornea, Delhi, Published by Jaypee brothers medical publisher, $6^{\text {th }}$ edition 2015 , P98.

36) Khurana AK, Comprehensive Ophthamology, Diseases of Cornea, Delhi, Published by Jaypee brothers medical publisher, $6^{\text {th }}$ edition 2015 , P117.

37) Khurana AK, Comprehensive Ophthamology, Diseases of Cornea, Delhi, Published by Jaypee brothers medical publisher, $6^{\text {th }}$ edition 2015 , P122. 
38) Khurana AK, Comprehensive Ophthamology, Diseases of Cornea, Delhi, Published by Jaypee brothers medical publisher, $6^{\text {th }}$ edition 2015 , P124.

39) Santhakumari PK, A text book of Ophthalmology in Ayurveda, Diseases of Krishnamandalam, Published by author, $2^{\text {nd }}$ edition 2009, P-155.

40) Vaidya Yadavji Trikamji and Narayan Ram Acharya, Sushruta Samhita Uttartantra 5/4, By Sushruta with Nibandhasngraha Commentry of Shri Dalhanacharya, Varanasi, Choukhamba Surbharti Prakashan, 2012, P-602.

41) Ambika dutta shastri, Sushruta Samhita Uttartantra 5/5, Part II, By Sushrutha with Ayurveda Tantvasandipika commentary, Varanasi, Choukhamba Sanskrit Sansthan, 2012, P -31 .

42) Ambika dutta shastri, Sushruta Samhita Uttartantra 5/6-7, Part II, By Sushrutha with Ayurveda Tantvasandipika commentary, Varanasi, Choukhamba Sanskrit Sansthan, 2012, P -31 .

43) Kaviraj Atridev Gupta, Ashtang Sangraha, Uttarsthana $13 / 26$ by Vagbhata, Varanasi, Choukhamba Krishandas Academy, 2005, P-234.

44) Khurana AK, Comprehensive Ophthamology, Diseases of Cornea, Delhi, Published by Jaypee brothers medical publisher, $6^{\text {th }}$ edition 2015 , P103.
45) Samar K Basak , Essential of Ophthalmology, Diseases of the Uvea, Kolkata, Published by Current books international, $4^{\text {th }}$ edition 2008 , P210.

46) Samar K Basak , Essential of Ophthalmology, Diseases of the Uvea, Kolkata, Published by Current books international, $4^{\text {th }}$ edition 2008, P211.

47) Samar K Basak , Essential of Ophthalmology, Diseases of the Uvea, Kolkata, Published by Current books international, $4^{\text {th }}$ edition 2008 , P288.

48) Ambika dutta shastri, Sushruta Samhita Uttartantra 5/6, Part II, By Sushrutha with Ayurveda Tantvasandipika commentary, Varanasi, Choukhamba Sanskrit Sansthan, 2012, P-31.

49) Vaidya Yadavji Trikamji and Narayan Ram Acharya, Sushruta Samhita Uttartantra 5/6, By Sushruta with Nibandhasngraha Commentry of Shri Dalhanacharya, Varanasi, Choukhamba Surbharti Prakashan, 2012, P-603.

50) Khurana AK, Comprehensive Ophthamology, Diseases of Cornea, Delhi, Published by Jaypee publisher, $6^{\text {th }}$ edition, $\mathrm{P}-102$. 